http://dx.doi.org/10.11646/phytotaxa.167.2.1

\title{
Three new species of Markea (Solanaceae, Juanulloeae) from Colombia
}

\author{
ANDRÉS OREJUELA ${ }^{1}$, CLARA INÉS OROZCO ${ }^{1} \&$ GLORIA BARBOZA $^{2}$ \\ ${ }^{1}$ Instituto de Ciencias Naturales, Universidad Nacional de Colombia, Apartado 7495, Bogotá, Colombia. \\ E-mail: ciorozcop@unal.edu.co,aaorejuelar@unal.edu.co,gbarboza@imbiv.unc.edu.ar \\ ${ }_{2}^{2}$ Instituto Multidisciplinario de Biología Vegetal (IMBIV-CONICET). Facultad de Ciencias Químicas, Universidad Nacional de \\ Córdoba, Haya de la Torre y Medina Allende, CC 495, CP 5000. Córdoba, Argentina.
}

\begin{abstract}
Three new species of Markea from Colombia are described and their morphological affinities and conservation status are discussed. Markea hunzikeri is different from other species of Markea because it presents a 3-lobed calyx and 3-lobed stigma. Markea huilensis shows affinity with Markea lopezii and Markea epifita, from which it differs by its exerted anthers, tubular-campanulate corolla and fruit with leathery, black, non-translucent exocarp when dry. Markea purpurea is clearly differentiated from other species in this genus by its very reduced, extra-axillary, short-pedunculate inflorescence, generally bearing one short-pedicellate or sessile flower with corolla dark purple or black inside. For new species illustrations, photographs of live plants and distribution maps are presented. As a tool for species identification of Markea, this paper is accompanied by a key to all species currently recognized in the genus. Additionally, photographs of live plants for most of the species of the genus are included.
\end{abstract}

Key words: Colombia, Hawkesiophyton, Juanulloeae, Markea, Solanaceae, taxonomy

\section{Resumen}

Se describen tres especies nuevas de Markea para Colombia y se discuten sus afinidades morfológicas y estado de conservación. Markea hunzikeri se distingue fácilmente de otras especies de Markea por su cáliz y estigma 3-lobulados. Markea huilensis es semejante a Markea lopezii y Markea epifita, de las que se diferencia por sus anteras exertas, corola tubular-campanulada y fruto con exocarpo coriáceo, negro y no translúcido en material de herbario. Markea purpurea se diferencia fácilmente de otras especies del género por su inflorescencia muy reducida, corto pedunculada, de posición extra-axilar, generalmente con una flor cortamente pedicelada o sésil, de corola púrpura en su interior. Para las nuevas especies se presentan ilustraciones, fotografías en vivo y mapas de distribución. Como herramienta para la identificación de las especies de Markea, este artículo va acompañado de una clave para todas las especies reconocidas actualmente en el género. Adicionalmente, se incluyen fotos en vivo para muchas de las especies del género.

Palabras clave: Colombia, Hawkesiophyton, Juanulloeae, Markea, Solanaceae

\section{Introduction}

Markea Richard (1792: 107) (Solanaceae) is a neotropical genus of the subfamily Solanoideae and belongs to the tribe Juanulloeae Hunz. (Hunziker 1977, 1979, 1997; Knapp et al. 1997; Knapp 1998). The species of Markea are epiphytic or hemi-epiphytic vines or shrubs, distributed from Panama to Bolivia and Southern Brazil (Hunziker 1997, 2001; Knapp et al. 1997). Most of its species grow in primary forests from sea level to $3000 \mathrm{~m}$. The highest diversity is found in the Colombian and Ecuadorian Andes (Hunziker 1997, 2001) while the highest concentration of species is present in Colombia with 13 of the 20 species currently recognized in the genus, including the three new species described in this paper.

In a most recent phylogenetic study for Solanaceae, Olmstead et al. (2008) recognize tribe Juanulloeae as a natural group. However, the circumscription of this tribe has been historically controversial, specifically regarding the inclusion of the genus Solandra Swartz (1787: 300), and more recently, Schultesianthus Hunziker (1977: 35) (Knapp et al. 1997; Hunziker 2001; Olmstead et al. 2008). Additionally, different concepts have been formulated on the status 
- Calyx length usually less than the midpoint of the corolla length in flower anthesis. Apex of the calyx lobes acuminate to largely

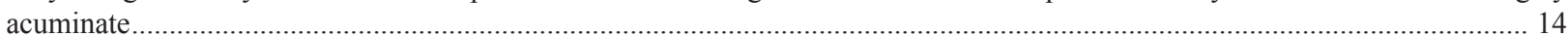

11. Leaf blades coriaceous, margin revolute. Indument with abundant branched trichomes. Ovary 4-locular. Southern Ecuador ..........

Leaf blades membranaceous, margin flat. Indument with simple trichomes. Ovary 2- locular ....................................................12

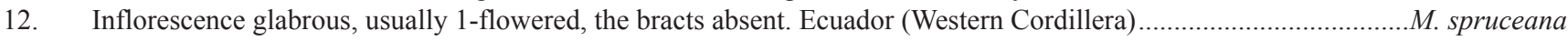

Inflorescence hairy, usually 4 or more flowered, the bracts stipule-like and conspicuous. ........................................................13

13. Indument densely pilose on the whole plant. Southwestern Colombia and northwestern Ecuador....................... pilosa (Fig. 4G)

Indument sparsely present to glabrescent. Colombia (Western Cordillera) ............................................... antioquensis (Fig. 4A)

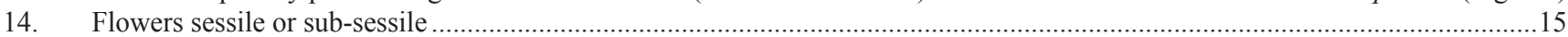

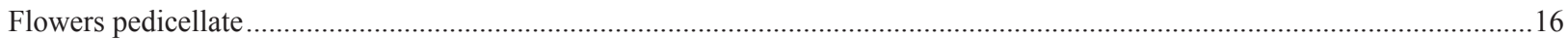

15. Leaf blades coriaceous, dark brown when dry in herbarium material, margin revolute. Axillary inflorescence. Brazil, Guyana, Surinam, Venezuela …........................................................................................................................... M. sessiliflora (Fig. 4I)

Leaf blades membranaceous, light brown when dry in herbarium material, margin flat. Extra-axillary inflorescence. Southwestern Colombia (Western Cordillera) ……...................................................................................................... purpurea $($ Fig. 8, 9)

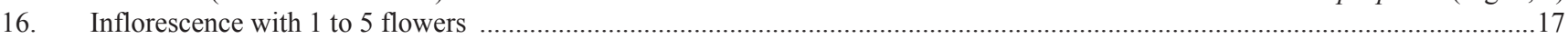

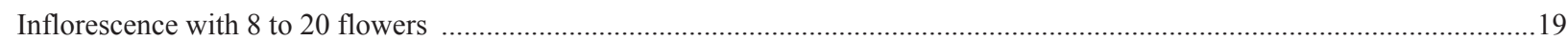

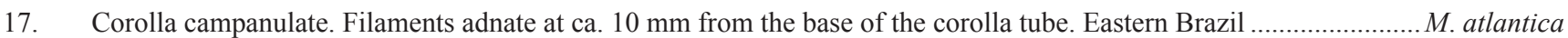
Corolla infundibuliform. Filaments adnate at $25-40 \mathrm{~mm}$ from the base of the corolla tube …...............................................18

18. Indument with simple trichomes; margin of leaf blade ciliate. Apexes of the corolla lobes obtuse or rounded. Colombia, Brazil, Peru (Amazon basin) ............................................................................................................................. formicarum (Fig. 4C) Indument with branched trichomes; margin of leaf blade non-ciliate. Apexes of the corolla lobes acute. Eastern and Southeastern Colombia (Eastern Cordillera, low slopes and Amazon low lands) ......................................................... plowmanii (Fig. 4H)

19. Calyx lobes shortly acuminate. Narrow part of the corolla tube protruding from the calyx in flower anthesis. Bracts absent or inconspicuous. Lesser Antilles, Northern Brazil, French Guiana, Guyana and Venezuela................................. M. longiflora (4E) Calyx lobes largely acuminate. Narrow part of the corolla tube included in the calyx in flower anthesis. Bracts linear and conspicuous. Southern Colombia and Northern Ecuador (low slopes and Amazon low lands) .............................. M. harlingiana

\section{Acknowledgments}

We are grateful to the curators of COL herbarium at the Instituto de Ciencias Naturales, Universidad Nacional de Colombia, Bogotá, to others Colombian herbaria, to CORD herbarium at the Instituto Multidisciplinario de Biología Vegetal, Universidad Nacional de Córdoba, Argentina, and to the curators of F, MO, QCA and QCNE herbaria. Our thanks to the "División de Investigación (DIB)" from the Universidad Nacional de Colombia, Bogotá, project DIB13574, and to the "Programa Jóvenes investigadores e innovadores" of COLCIENCIAS. We extend our thanks to Marcela Morales for the excellent illustrations accompanying this paper, to Julio Betancur and Paola Pedraza (NSF " Flora of Las Orquideas National Park project" DEB 1020623) and to the "Parques Nacionales Naturales de Colombia" for their collaboration in the fieldwork, where the type specimen of $M$. hunzikeri was collected. To the owner of the private reserve "Meremberg" for his support during the fieldwork, where the specimen type of M. huilensis was collected. To Mauricio Flórez Paí for his support in the Natural reserve "Rio Nambí". To Jorge Mario Vélez for his comments and discussions of the early version of the M. huilensis description and for his accompanying during the field work. Our thanks to the people who provided some photographs accompanying this paper, to Jhoana CastilloGarcía and Thomas C. Andres for their help getting M. purpurea material, and to Amparo Rueda for her revision of the English text. Finally, we thank the reviewers for their critical comments and suggestions. This paper presents part of the results of the Master's thesis of the first author.

\section{References}

Anton A.M. \& Barboza, G.E. (2007) Armando Theodoro Hunziker (29 August 1919-12 December 2001). In: Spooner, D. M., Bohs, L., Giovannoni, J., Olmstead, R. G. \& Shibata, D. (editors) Solanaceae VI: Genomics meets biodiversity. Acta Horticulturae (ISHS) 745: 551-564.

Cuatrecasas, J. (1959) New chiropterophilous Solanaceae from Colombia. Journal of the Washington Academy of Sciences 49: $269-271$. D'Arcy, W.G. (1973) [1974] Solanaceae. In: Woodson, R. E. \& Schery, R. W. Jr. (editors) Flora of Panama. Annals of Missouri Botanical Garden 60: 573-780. http://dx.doi.org/10.2307/2395139

Donnell Smith, J. (1897) Undescribed plants from Guatemala and other Central American republics XVII. Botanical Gazette 23: 1-14. 
http://dx.doi.org/10.1086/327456

Ducke, A. (1915) Plantes nouvelles ou peu connues de la région amazonienne. Solanaceae. Archivos (Arquivos) do Jardim Botânico do Rio de Janeiro 1: 54-57.

Hunziker, A.T. (1977) Estudios sobre Solanaceae VIII. Novedades varias sobre tribus, géneros, secciones y especies de Sud América. Kurtziana 10: 7-50.

Hunziker, A.T. (1979) South American Solanaceae: A synoptic survey. In: J. G. Hawkes, R. N. Lester \& A. D. Skelding (editors) The Biology and Taxonomy of the Solanaceae. Academic Press, London, pp. 49-85.

Hunziker, A.T. (1985) Estudios sobre Solanaceae XX. Markea lopezii, nueva especie de Colombia. Lorentzia 5: 9-12.

Hunziker, A.T. (1997) Estudios sobre Solanaceae LIII: Revisión de las especies de Markea. Kurtziana 25: 67-113.

Hunziker, A.T. (2001) Genera Solanacearum. A.R.G. Gantner Verlag K.-G., Ruggell, 500 pp.

IUCN (2012). IUCN Red List Categories and Criteria: Version 3.1. Second edition. Gland, Switzerland and Cambridge, UK: IUCN. iv + $32 \mathrm{pp}$.

Knapp, S. (1998) New Species and Notes on the Natural History of Markea (Solanaceae) from Colombia and Ecuador. Novon 8: $152-161$. http://dx.doi.org/10.2307/3391987

Knapp, S., Persson, V. \& Blackmore, S. (1997) A phylogenetic conspectus of the Juanulloeae (Solanaceae). Annals of the Missouri Botanical Garden 84: 67-89.

http://dx.doi.org/10.2307/2399954

Linden, J.J. (1853) Trianaea. In: Prix-courant 8: 4.

Miers, J. (1849) XXI. Contributions to the Botany of South America. On the genus Ectozoma. Annals and Magazine of Natural History, including Zoology, Botany, and Geology, ser. 2, 4: 185-193.

Miers, J. (1849) XXVIII. Contributions to the Botany of South America. On the genus Dyssochroma. Annals and Magazine of Natural History, including Zoology, Botany, and Geology, ser. 2, 4: 250-251.

Nee, M. (2011) Familia Solanaceae. In : Idárraga, A., Ortiz, R., Callejas R. \& Merello, M. (eds.) Flora de Antioquia: Catálogo de las plantas vasculares. vol. II. Listado de las plantas vasculares del departamento de Antioquia. Editorial D’ Vinni, Bogotá, pp. 882-897.

Olmstead, R.G., Bohs, L., Migid, H.A., Santiago-Valentin, E., Collier, S.M. \& García, V.F. (2008) A molecular phylogeny of the Solanaceae. Taxon 57: 1159-1181. Avaliable from: http://depts.washington.edu/phylo/OlmsteadPubs/Olmstead_et_al_2008.pdf(accessed 8 May 2014)

Persson, V., Knapp, S. \& Blackmore, S. (1994) Pollen morphology and systematics of tribe Juanulloeae A.T. Hunziker (Solanaceae). Review of Palaeobotany and Palynology 83: 1-30. http://dx.doi.org/10.1016/0034-6667(94)90054-x

Richard, L.C.M. (1792) Catalogus plantarum, ad societatem, ineunite anno 1792, e Cayenna missarum a domino Le Blond. Actes de la Société d'Histoire Naturelle de Paris 1: 105-114.

Rodríguez, R.E.F. (2006) Una nueva especie de Markea (Solanaceae: Juanulloeae) para el Perú. Arnaldoa 13: 306-313.

Ruiz, L.H. \& Pavon, J.A. (1794). Florae Peruvianae, et Chilensis Prodromus, sive novorum generum plantrum peruvianum, et chilensium descriptiones et icones. Madrid, $153 \mathrm{pp}$. http://dx.doi.org/10.5962/bhl.title.11759

Särkinen, T., Bohs, L., Olmstead, R. \&. Knapp, S. (2013) A phylogenetic framework for evolutionary study of the nightshades (Solanaceae): a dated 1000-tip tree. BMC Evolutionary Biology 13: 214.

http://dx.doi.org/10.1186/1471-2148-13-214

Stehmann, J.R. \& Giacomin, L.L. (2012) Markea atlantica (Solanaceae): a new species of tribe Juanulloeae disjunct from its core distribution. Systematic Botany 37: 1035-1042.

http://dx.doi.org/10.1600/036364412x656581

Swartz, O. (1787) Solandra, et nitt Órt-flågte från Vesf-Indien. Kongl. Vetenskaps Academiens Nya Handlingar 8: $300-306$. 